\title{
AUTHENTIC MEDIA RESOURCES AS MEANS OF FORMATION OF INTERCULTURAL COMMUNICATIVE COMPETENCE FOR PROSPECTIVE FRENCH LANGUAGE TEACHERS / LECTURERS
}

\section{Oksana Bigych ${ }^{1}$ \\ Diana Rusnak ${ }^{2}$}

DOI: https://doi.org/10.30525/978-9934-588-38-9-2

Abstract. Intercultural communicative competence (ICC) is one of the generating goals in students - prospective teachers / lecturers of foreign, especially French, language. Media resources are sorted out among modern means of formation of intercultural communicative competence. We consider that their main feature is authenticity. The objective of the article is the introduction of the place and role of the authentic media resources within the process of forming ICC for prospective teachers / lecturers of the French language during the classroom language training. As a result of our research we distinguish such types and kinds of authentic media resources that are used in teaching of foreign languages and cultures in high educational institutions: published media resources, i.e., articles in newspapers and magazines, advertising texts; sound media resources, i.e., songs, radio programs, radio ads; visual media-resources, i.e., photos, commercials, comic pictures (comics); audio-visual (mixed) media resources, i.e., TV programs, movies, cartoons, video commercials; electronic media resources, i.e., multimedia reports, articles in the Internet, etc. Different kinds of authentic media resources as teaching means of the French language and culture are studied in the context of sociological, anthropological and semiotic approaches. In terms of sociological approach, any cultural phenomenon can be seen as a social problem and can study its general role in the society. The semiotic

\footnotetext{
${ }^{1}$ Doctor of Pedagogical Sciences, Professor,

Professor at the Department of Methodology of Foreign Language Teaching and Information Technologies,

Kyiv National Linguistic University, Ukraine

ORCID: https://orcid.org/0000-0002-7997-8487

${ }^{2}$ Candidate of Pedagogical Sciences, PhD in Pedagogical Sciences,

Associate Professor of the Department of Romance Philology and Translation,

Yuriy Fedkovych Chernivtsi National University, Ukraine
} 
approach studies the culture as a language of signs that can save and spread information. Inside the context of the anthropological approach customs, traditions, values, behavior, rituals are studied. Each kind of authentic mediaresource needs the special methods of students' work with it as with the source of modern linguistic and extra-linguistic information about the country of studied language and its culture and the world culture in general. At once authentic media resources are as a compulsory mean and condition of teacher / lecturer's creation of special foreign cultural environment for formation of students' intercultural communicative competence at a lesson of the foreign language practice. Orienting to the future professional occupation of French language teacher / lecturer, students make their own lists of authentic media resources as means of formation of different kinds of foreign language and foreign culture competence.

\section{Introduction}

The training for specialist who is ready not only for the interlingual but for the intercultural communication is the major priority of the modern education. Notably, it is written in the Recommendations of the European Council [7] according to the language education that the language teaching should allow to develop the multilingual and intercultural competences within students, which are able for living in social cohesion and for providing a society of peace. Due to the intercultural approach for teaching, it is possible to achieve those factors that are aimed for developing the student's acceptance of foreigners, relativity, tolerance and respectful attitude towards them.

Students have to orient within the phenomena of someone's else way of life, other conscience, the feeling system, hierarchy of values: perceive and comprehend some facts about foreign culture, compare it with own belief and cultural experience, find out differences and similarities; critically comprehend all facts about foreign culture, thus enrich the own vision of the world (G.V. Elizarova, V.V. Safonova, J.-C. Beacco, L. Byram, L. Porcher).

The question is significant for teaching prospective French language teachers / lecturers, who have to master previous competences not only for their own needs, but for teaching students about their future profession.

Firstly, the process of teaching needs the formation of teaching elements (educational content - what has to be studied), thus it foresees the kit of the 
teaching means (with the help of what to teach), among which the authentic teaching materials are singled out.

The use of authentic materials in the teaching of foreign language and culture is the major principle of the communicative approach, according to which the process of teaching foreign language and culture simulates the process of the verbal communication.

The authentic materials that do not fit for teaching, give the possibility to get acquainted students with the real world of the country that is learned by foreign language and culture and serve as an additional motivational source for their mastering. The rapid developing of the innovative informational and media technologies contributes to active use of the authentic media recourses into the educational process that show the modern language and culture of their natives.

Nowadays there are no doubts that such authentic materials can be effective mean of teaching foreign language and culture, but the question how to combine the teaching of language and culture at practical language classes in high educational institutions, which are based on authentic mediaresources, is still essential.

Despite the media resources are indispensable source of not only language but also of linguo-sociocultural information, our supervision over the process of teaching foreign language and culture demonstrates that the work through authentic materials in classroom language training is aimed on formation of foreign linguistic or speech competences; it is implicit in most cases in teaching of culture.

Anyway, on the one hand, the importance of this research is attributable to the need in constant renew of additional teaching means and their use in the educational process, especially for teaching foreign language and culture, on the other hand there is the lack of development of this issue in the context of the intercultural approach.

The question of media resources' use (printed, radio, television and the Internet resources) at the lesson has been analyzed for a long time in the methodology of teaching foreign language and culture (P.U. Melnyk, V.S. Pachuk, L.V. Petryk, D.A. Rusnak, V.V. Safonova, O.I. Shevarshynova, T.O. Yakhniuk, Th. Lancien, M.-F. Narcy-Combes, L. Porcher, G. Zarate). The relevance of the media technologies' use in the educational process in high educational institutions was proved by scientists, because media 
resources could rise the students' motivation in the learning, could provide the interactivity in studying, vary task and forms of giving the information thus they could improve the effectiveness of learning the educational material by students, could activate learning, encourage creativity, develop critical thinking, etc.

We have already analyzed different media texts as means of forming the media-competence for prospective lecturers of the French language (D. Rousnak, 2015), French feature films as means of upbringing, some means of teaching the prospective French language teachers of the monologue (D. Rousnak, 2017). Our last research foresaw the learning of specific context of media texts as a mean of teaching the prospective French language lecturers of intercultural communication (O. Bigych, D. Rousnak, 2019; D. Rousnak, 2019).

At the same time the question of the use of media resources as means of teaching foreign language and culture cannot be considered as entirely learned, mostly the problem of forming the intercultural communicative competence (ICC) with different types of authentic media-resources for students - prospective French language teachers / lecturers still needs the independent research.

The objective (aim) of the article is the introduction of the place and role of the authentic media resources within the process of forming ICC for prospective teachers / lecturers of the French language during the classroom language training. At the beginning, we will analyze all types of media documents in the context of semiotic, anthropologic and sociological approaches to achieve the desired aim, then, according to the content of ICC, we will identify their role and place in the educational process.

For achieving the aim of our research, the following tasks are presented:

- to clarify all components of ICC;

- to analyze various types of media documents in the context of semiotic, anthropological and sociological approaches;

- to identify the role and place of the authentic media resources in the educational process according to the context of ICC;

- to offer some media-resources for forming ICC among students during language training classes.

The novelty of our research is connected with the first review of the question of how to use media-resources for forming ICC within the future 
French language teachers / lecturers in the context of anthropological, semiotic and sociological approaches.

The practical meaning of our research is consisted of selection and analyses of French language media resources that encourage formation of ICC among students at the language training classes.

The theoretical bases of the research are: the theory of communication (F.S. Bazevich, S.G. Ter-Minasova, A.P. Sadohin), the theory of interrelated teaching of the language and culture (E.M. Vereschaguin, V.G. Kostomarov, N.D.Gal'skova, N.I. Guez, V.V. Safonova, J.-C. Beacco, M. Byram, Ch. Puren), and the theory of mass communication (G.G. Pochepzov, S. Chaumier et E. Mairesse, A.A. Moles, B. Péquignon). In addition, we rely on data of the theory of cultural signs (R. Bartes, M. Baujouret, J. Ehrmann, U. Eco), cultural anthropology (C. Kluckholn, M.-J. Herrskovits, C. LéviStrauss), and sociology of culture (P. Bourdieu, L. Porcher). The researches are performed in the content of the intercultural approach to the learning of ICC.

The research materials are digital, iconographic, audio and video resources with easy access in the Internet.

\section{Components of intercultural communicative competence for prospective French language teachers / lecturers}

During the educational process of foreign language and culture at high educational institutions students are mastering international competence which is explained as a skill of communication with representatives of other cultures and are engaging in partnerships within the different cultural situations [6; 12: 14].

As the result of the analysis of methodological literature we add to ICC the knowledge of the mother tongue and international culture (sociocultural knowledge), communicative skills in different communicative situations (speaking skills, listening, reading, writing) and behavior skills in cultural situation (skills of action). The fundamental criterion of intercultural teaching is the analogy with the native language and culture and the developing of student's respect towards foreigners and their tolerant attitude to his/her uncommon cultural behavior. So, the content of the ICC formation includes $[6 ; 12 ; 14]$ :

- customs and traditions, the way of life of the nation whose language is studied; 
- the coincidence and difference in values and behavior norms of native culture $(\mathrm{C} 1)$ and foreign culture $(\mathrm{C} 2)$;

- cultural differences between $\mathrm{C} 1$ and $\mathrm{C} 2$;

- the nature and risk of stereotypes and prejudices (C2);

- the process of cultural shock;

- non-verbal communication (mimics, gestures);

- the open treatment, interest, empathy and judgement without any evaluation;

- communicative strategies which are needed for communication inside the intercultural context.

Thus, the ICC includes cognitive, affective and pragmatic components, each of them needs some specific approaches, teaching methods and techniques.

Within the context of the artificial bilingualism (in the classroom language training courses in high educational institutions) the teaching of the intercultural communication streamlined proceeds with the help of supportive means of teaching, especially with the help of authentic media resources. According to G. Zarat [13], for formation of the ICC authentic materials, mostly media, can be an irreplaceable support for teaching because they show all issues of the modern society, they introduce inventions and modern technologies, inform about current news, etc. At the same time, some professionals in the theory of mass communication notify that the broadcast of the modern culture occurs generally through the mass-media and the meaning of the media culture becomes the main in the context of the modern culture. Through the technical means (press, radio, television, movies) the means of mass-media information influence on the modern person, fill up his/her leisure, inform about the world, educate, develop and entertain in such a way influence upon his/her thoughts and mentality [2, p. 76-79]. However, media texts can form the view about the level of the language culture in society also about tastes, behavior, life principles, etc.

It has been already mentioned that in our previous researches we have analyzed media resources for different educative purposes. Therefore, we identify such media resources that are used in teaching of the ICC:

- printed (articles in newspapers and magazines, advertising texts);

- audio (radio broadcast, commercial);

- iconographic (photos, ad, comics);

- audio-visual (TV programs, movies, cartoons, video commercial); 
- digital (multimedia reports, internet-articles etc).

The gaining of knowledge about native and foreign cultures and formation of communicative skills in different situations becomes possible in the classroom language training courses on the base of authentic media-resources. Active intercultural skills (comportments) are forming within the conditions of direct contact with the presentation of their culture.

\section{The forming of intercultural communicative competence in the context of sociological, anthropological, and semiotic approaches}

Under the social circumstances, there are different approaches according to the culture studying among which some methodologists distinguish sociological, anthropological and semiotic approaches [8]. We shall analyze media resources as means of teaching the French language and culture in the context of these approaches.

In terms of sociological approach, any cultural phenomenon can be seen as a social problem and studies it general role in the society. Anyway for the analyze of the topic "Sport" in France the statistics on sport is provided, the amount of clubs and federations etc., the general role of sport at lessons, types of sport for different social levels and professional categories, politics which is held by the country regarding the sport, etc. The sociological approach uses numbers, different surveys according to themes of research furthermore these data can be found in the French press (newspapers, magazines, news).

At the core of the anthropological approach, the person is found not numbers and the cultural question is regarded through the daily life. Inside the context of the anthropological approach customs, traditions, values, behaviour, rituals are studied. If we are talking about the topic "Sport" within the anthropological approach in the French life the time and sport venue, tastes, preferences and attitude towards the sport are considered. Unlike the sociological approach, the anthropological approach studies current data that can be got from media resources (articles, radio-TV programs, multimedia reports, pictures in magazines, etc.). Actually, these data are studied within the context of multicultural approach when the information about cultural event has been received and are compared with data about the native culture in personal society.

The semiotic approach studies the culture as a language of signs that can save and spread information. These signs can be words, pictures, images, 
sounds and present cultural connotation, myths, which are understandable for all members of society and therefore this cultural material is the hardest one for foreigners' comprehension, if they do not know the special background knowledge.

Usually such cultural signs are used in commercial, songs, and feature films.

\subsection{The iconographic means of forming the intercultural communicative competence}

Different pictures, comics, and posters, everything that transmits the message content through the picture are referred to the iconic or iconographic documents. In the methodology of teaching language and culture, iconographic documents are usually used as an illustrative material for easier comprehension of the oral or written text, for introducing and revision of lexical units, for developing of speaking skills [9, p. 264 ]. According to our opinion for the analysis of cultural signs the best mean is advertising and humorous picture or comics.

The advertisement often uses cultural signs, which are understandable for all members of society for attracting customer's attention for the advertised product and force him/her to buy this product. Some professionals in the area of socio-psychology emphasize that ad has an influence on people's behavior, forms the specific way of life. It reinforces the set of values, ideals, stereotypes and preferences in the consciousness of the customer, thus makes the regular impact on the life of different social groups [1].

According to U. Eco [10], the advertisement is the semiotic thing that has several coded levels, which have been created to cause an emotional reaction and encourage it for demanded things.

Within his research, R. Bart [5] has analyzed visual image. He has proved that the meaning of any ad image always has intentional character and in any ad images there are signs that are made emphatically for their better reading. In the ad message $\mathrm{R}$. Bart presents three levels:

1. Linguistic message, which is the text of the advertisement. The knowledge of language is only needed for its decoding.

2. Iconic message, which has no code and has denotative meaning. For understanding this image, the simple ability to comprehend visual images is needed. 
3. Iconic message where the specific code is hidden (symbolic image of objects, row of discrete signs that the image has) with the presence of a connotative meaning. For reading such iconic image, we need to make an analysis of associations, which are caused by these signs.

For instance, in the ad of dairies Chambourcy (Figure 1) there is a linguistic message «A 356 ans vous ferez la crème caramel aussi bien qu'elle» (When you are 356 years old you will make the caramel cream as good as she makes), the iconic message with denotative meaning the jar with caramel cream and the iconic message with connotative meaning the lady who is wearing historical costume, pours milk - the image of milkmaid reminds La Fontaine character La laitière, that hints on the quality and traditional production of this advertised product.

For emphasizing the origin of French beer, which is famous for Germany more than for France, the beer ad 1664 (Figure 2) introduces the iconic message without any cultural code - the pint of beer and the iconic message with cultural code - Paris with the Eiffel tower. The linguistic message Le goût à la française (the French taste) completes the image of France.

In the ad of car Hundai (Figure 3) there are iconic messages without cultural code - the car and with cultural code - the image of rooster which is the symbol of France. The linguistic message "HUNDAI devient HUNDAI MOTOR FRANCE" proves the French origin of the product.

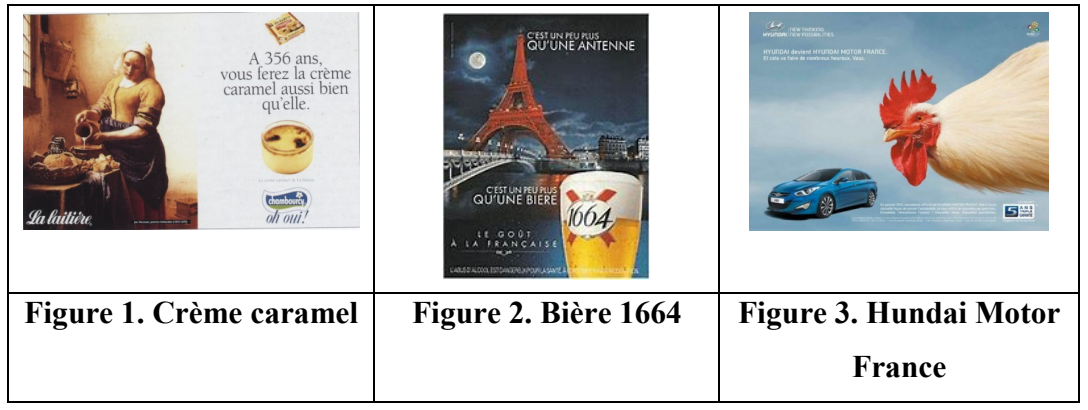

Mentioned cultural codes are famous for the whole world and they need not any explanations for students. However, there are different types of cultural codes in the advertisement, the understanding of which needs solid sociocultural knowledge and practice at French language training classes. 
We have already analyzed different cultural codes: city, countryside, industrial, traditional culture, gender and age subculture in the context of ad stereotypes [3]. Thus, in the advertisement of cheese and wine, dairies, there is an accent on the representatives of countryside with the hint on traditional production of these goods, whereas the process of their production in most cases is industrial (Figure 4). The image of baby in the ad is associated with health and youth (Figure 5) and the image of young man is associated with penniless and carelessness (Figure 6), etc.

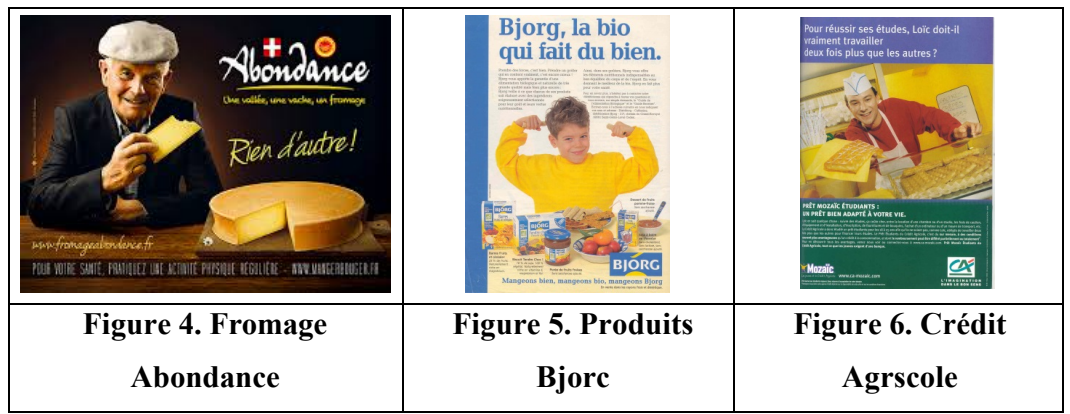

The humorous picture is one more media resource, which presents the specific interest within the context of the semiotic approach. The periodic press, i.e., newspapers, magazines, that are accessible in the Internet, are also the source of humorous picture. According to the use of humorous pictures at the French language training classes, we show that humor as well as advertisement introduces mentality, it is based on social codes and communicative norms and has the national character (local peculiarities in each country). In accordance with J.S. Gard [11], the humor is a form of conscious, which shows the reality in a comic way for attracting attention toward funny and weird life aspects. We cannot mention that there is a periodic French publication Charlie Hebdo, which tells about different problems of the modern society (political, economic, religious) in a funny way. Charlie Hebdo exists in printed format and in the Internet (http://chaliehebdo.fr/).

The main feature of the French humour is absence of bans and limits. Anything can become an object of satire and humour. J. Gard [11, p. 67] has noticed that angry and foolish humour with some tone of pornography de- 
spite all things is legal form of satiric communication in France. Therefore, the use of humorous pictures at classroom needs to be chosen really very carefully by the French language teacher / lecturer.

Thus, in the context of the semiotic approach humorous pictures can have hidden meaning, can have specific cultural signs, which are known for native speakers. For instance, the picture L'école a bien changé (The school was changed) (Figure 7) suggests the modern state if the education in France introduces the loss of the teacher's credibility. So, we can see in the first picture that in years ago the teacher told the student about his poor results and said that the student should work more harder: «Tu as 37\% en français, tu devras travailler plus fort!». In the second picture, in modern times, angry parents reproach the teacher for bad results of their son, who is nearby them standing in nice mood: «Notre fils a $37 \%$ en français, vous devrez travailler plus fort!!!».

When we are talking about the hard teacher's job, we can mention two next comics (Figure 8,9). In the doctor's office (Figure 8) the patient says that he is a teacher but he cannot tell all about his health problems: "Voilà, docteur. Je suis prof et je ...». The doctor diagnosed him according to his job and prescribed him antidepressants for 6 months: «Paarfait. Des anti-dépressants pour 6 mois». In the Figure 9 angry father asks his daughter: «Comment ça, tu veux devenir maîtresse quand tu sera grande?!! Tu veux finir comme ta mère!!!» (Do you want to be a teacher like your mother, don't you? Do you want to end up like your mother?). The girl's mother is standing nearby. We can only guess, what he is mentioning.

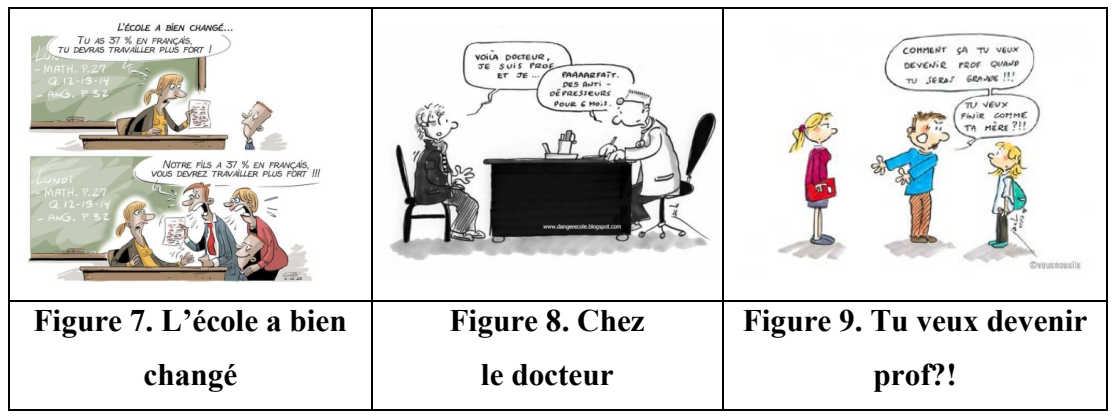

These comics we can use at language training classes during the topic "Education" and to compare them with the similar situation in our country. 


\subsection{Audio and video media resources as means of forming the intercultural communicative competence}

Various radio and TV programs allow to get different knowledge, which are the components of the ICC: about social problems, lifestyle, behaviour, faith, religion and values in society, and they encourage students to form the ICC in the context of anthropological and sociological approaches.

For instance, French sites Savoirs.rfi.fr (https://savoirs.rfi.fr/fr) and France Culture (https://www.franceculture.fr/) suggest radio broadcasts that can be used during the educational process. Particulary, there is a rubric for learning the French language Apprendre le français (https://savoirs.rfi. $\mathrm{fr} / \mathrm{fr} /$ recherche/rubrique/apprendre/editorial/questionnaire/objectif/apprendre-et-perfectionner-le-francais-2707) on the site Savoir.rfi.fr, where each week modern news appears with various assessment tasks that can be done online or in PDF format.

Different news' themes have separate rubrics (culture, society, economics, environment, health, francophonies, etc), the search of information that is needed becomes easier with their help. Moreover, different methodological guidelines can be found in Fiches pédagogiques, which can be very useful for the prospective French language teachers / lecturers (https://savoirs. rfi.fr/fr/recherche/rubrique/apprendre/objectif/enseigner-le-francais-2708/ editorial/article_pedagogique). Each radio program broadcasts 2-3 minutes and this material can be studied during the language training classes.

For example, the radio broadcast Décrire Noel autour du monde (https://savoirs.rfi.fr/fr/apprendre-enseigner/societe/decrire-noel-autourdu-monde) allows to introduce for students Christmas traditions in various countries.

It is possible to find out what women are thinking about chivalry with the help of radio program Débattre sur la galanterie (https://savoirs.rfi.fr/fr/ apprendre-enseigner/societe/debattre-sur-la-galanterie), the opinions of the Frenchmen on the life in Europe are possible to know with radio broadcast L'Europe au quotidien: libre circulation (https://savoirs.rfi.fr/fr/apprendre-enseigner/geopolitique/leurope-au-quotidien-la-libre-circulation).

The chances to study abroad following the Erasmus program are presented for students with L'Europe au quotidien: le programme Eurasmus (https://savoirs.rfi.fr/fr/apprendre-enseigner/geopolitique/leurope-au-quotidien-le-programme-erasmus). 
The information on the French environment is performed on Objectif zéro déchet! (https://savoirs.rfi.fr/fr/apprendre-enseigner/environnement/ objectif-zero-dechet/1), Ecotourisme dans le sud de la France (https:// savoirs.rfi.fr/fr/apprendre-enseigner/environnement/ecotourisme-dans-lesud-de-la-france/1) and Balade sur les bords de Seine (https://savoirs.rfi. $\mathrm{fr} / \mathrm{fr} /$ apprendre-enseigner/environnement/balade-sur-les-bords-de-seine/1).

Obviously, it is not the whole list of radio broadcasts, only few of them are introduced in our article. As we previously noticed, the main advantage that Savoirs.rfi.fr has, is short duration of broadcasting and its help in developing listening skills.

The next informational platform TV5MONDE (http://www.tv5monde. $\mathrm{com} /$ ) offers methodological guidelines for all levels (A1-C1) on the base of TV broadcasting, songs, ad, short-cuts, interviews with celebrities, etc. A rubric 7 jours sur la planète (https://apprendre.tv5monde.com/fr/exercices/7-jours-sur-la-planete?field_niveau_tid=21) is of a particular note, where are TV reports with methodological guidelines can be found, there is offered how to greet each other in a proper way, with the help of TV report Comment faire la bise (https://apprendre.tv5monde.com/fr/exercices/b1-intermediaire/comment-faire-la-bise). The TV report Marie Antoinette icone planetaire (https://enseigner.tv5monde.com/fiches-pedagogiques-fle/marie-antoinette-icone-planetaire) explains how the queen Marie Antoinette, who had been hated by people, has become an icon all over the planet.

About the highest European steel sculpture, which is twice as high as the Statue of Liberty, can be known with the help of video-report Bernar Venet et lart XXL (https://enseigner.tv5monde.com/fiches-pedagogiques-fle/bernar-venet-et-lart-xxl).

To know about other countries where French is studied is possible in the rubric Destination Francophonie. Within the intercultural approach interesting reports about Ukraine there are the resources Destination Ukraine (1) (http://www.tv5monde.com/emissions/episode/destination-francophonie-destination-ukraine-1) and Destination Ukraine (2) (http://www. tv5monde.com/emissions/episode/destination-francophonie-destination-ukraine-2), which are dedicated to one of the well-known French novelist Honoré de Balzac and his connections with the other country.

In other reports there are presented the Ukrainian cities. Thus, the TV report Destination Kiev (https://apprendre.tv5monde.com/fr/exercices/ 
b1-intermediaire/destination-kiev) tells about the history of the capital of Ukraine and about the organization of debates in the French language under the game Le parlement européen. The program Destination Odessa Destination Odessa (http://www.tv5monde.com/emissions/episode/destination-francophonie-destination-odessa) tells about the development of the French language in Odesa.

In the rubric Tourisme en France (https://apprendre.tv5monde.com/fr/ exercices/tourisme-en-france) it is offered to get acquainted with the French regions, lifestyles, and cuisine.

For instance, in the TV program Week-end à Noirmoutier (https://apprendre.tv5monde.com/fr/exercices/a2-elementaire/week-end-noirmoutier) it can be found about city Noirmoutier that is located on the coast of the Atlantic ocean. The TV program Vacances dans Le Gers (https://apprendre. tv5monde.com/fr/exercices/a2-elementaire/vacances-dans-le-gers) presents information about holidays in the Le Gers department on the southwest France. It is possible to visit the famous castle, where the duke of Mote Cristo has been imprisoned, with the help of video report Visite du chateau $d$ If (https://apprendre.tv5monde.com/fr/exercices/a2-elementaire/visitedu-chateau-dif). Some short-cuts of reports about the French regions $\mathrm{C} a$ bouge is represented by Alsace (https://apprendre.tv5monde.com/fr/exercices/a2-elementaire/ca-bouge-en-alsace), Côte d'Azur (https://apprendre. tv5monde.com/fr/exercices/a2-elementaire/ca-bouge-sur-la-cote-dazur), Bretagne (https://apprendre.tv5monde.com/fr/exercices/a2-elementaire/cabouge-en-bretagne) are presented.

All methodological guidelines introduce tasks while watching mute and sounded TV reports, testing can be done by checking general video comprehension, moreover the revision of lexical units and grammar references can be done.

The indispensable media resource for the ICC formation within students is a song. TV 5 monde offers a wide range of media lyrics in the rubric Paroles de clips (https://enseigner.tv5monde.com/fiches-pedagogiques-fle/ paroles-de-clips-0).

For example, it is possible to discuss with students people's values and life priorities with the help of video clip Plus haut (https://enseigner. tv5monde.com/fiches-pedagogiques-fle/plus-haut-0) by Claudio Capéo.

The freedom of choice and life priorities are used by John Mamann's songs On s'en fout (https://enseigner.tv5monde.com/fiches-peda- 
gogiques-fle/sen-fout) and Roi de France (https://enseigner.tv5monde. com/fiches-pedagogiques-fle/roi-de-france). In the song Laissons-les rêver (https://enseigner.tv5monde.com/fiches-pedagogiques-fle/laissons-lesrever-0) the author sings about the happiness and children's dreams.

The singer Rose sings about the life sense in her song Je compte (https:// enseigner.tv5monde.com/fiches-pedagogiques-fle/je-compte).

Themes of good and evil are represented in the song of the Canadian singer Natasha Saint-Pierre Un ange frappe à ma porte (https://enseigner. tv5monde.com/fiches-pedagogiques-fle/un-ange-frappe-ma-porte).

Relationships between parents and their children are illustrated in Mika's song Elle me dit (https://enseigner.tv5monde.com/fiches-pedagogiques-fle/ elle-me-dit).

Thus, the song and video clip are valuable audio and video materials that encourage students to form the ICC in the context of anthropological and semiotic approaches.

The advantage of audio and video media resources for the ICC formation becomes possible with the creation of particular cultural environment, which allows to develop the illusion of real communication by means of audio and video. According to O. I. Shevarshynova [4], the authentic video media texts are the source of the modern linguistic and extra linguistic information about the country which language and culture are studied, moreover about the culture all over the world, also it can be both source and condition for developing special cultural environment for formation of the ICC in student's educational process. Actually, these media texts show the real life of native speakers and video components make the comprehension of foreign speaking easier while listening and it creates an illusion of being in foreign environment.

\subsection{Printed media texts, which are used during language training courses}

The teaching of foreign language is linked with the culture and it is presented by the printed press (newspapers and magazines) during language training classes, the digital variant can be free accessed while searching through the Internet. It is possible to get acquainted with various French publications while accessing http://www.revue2presse.fr/home.php?cat=1. The popular French newspapers are Le Figaro, Le Monde, Libération, Le Parisien, La Tribune, 
La Croix, L"Equipe) and French magazines ELLE, Vogue, Marie-Claire, these materials are very popular with the Ukrainian readers.

Some specialists who are studying the mass-communication emphasize that the main feature of media-texts is normative orientation (the relevance of statements according to speaking format), communicativeness (linked with speaking tasks, which can provide the efficiency of communication, can transmit information, can show order, wish, etc), and also ethics (informational maintenance of the international balance between sent messages, that can be done with the help of objective and faithful information which is always used by journalists) [2, p. 92].

Different printed media texts publish current news, photos of celebrities, discuss current issues and sociological surveys, these materials are the didactic potential for the ICC teaching in the context of anthropological and sociological approaches. Here we can present responds to the questions on:

- How French students connect their studying and job: (https://www. francetvinfo.fr/replay-radio/le-plus-france-info/travailler-pour-etudier-lelot-de-plus-en-plus-commun-des-etudiants_1724623.html);

- Why Frenchmen are taking industrial actions: (https://fr.yahoo.com/ news/gr\%C3\%A8ve-massive-le-5-d\%C3\%A9cembre-190126742.html);

- What mistakes should be avoided while choosing food products: (https://www.ladepeche.fr/article/2018/07/21/2839592-alimentation-vraiou-faux-les-pieges-a-eviter.html);

- What consequences junk food can have: (https://www.preventionsante.eu/actus/consequence-de-la-malbouffe);

- How not to waste money on buying food: https://www.ouest-france.fr/ economie/consommation/gaspillage-alimentaire/);

- What Frenchmen are thinking about the weather forecasts: (https:// www.20minutes.fr/societe/2667323-20191204-changement-climatiquefaut-revoir-);

- Why Frenchmen are not pleased with the Christmas markets: (https:// www.20minutes.fr/strasbourg/2659755-20191125-strasbourg-vivementca-termine-quand-locaux-deja-marre-marche-noel), etc.

In accordance with methodology of teaching foreign language and culture, newspaper articles are the main material for reading, starting from B1 level and they can be the component for tests, which are related to checking of comprehension in writing and obviously for receiving the 
French certificates DELF/DALF [1]. Thus, the French course books include printed articles with methodological guidelines for the French reading tasks (Alter ego B1; Defi B1; Edito B1, Panorama 3; Taxi 3 etc.).

\section{Conclusions}

Consequently, the ICC is our target for forming the French language skills. Looking through the context of sociological, anthropological and semiotic approaches, the components of the ICC can be identified as the knowledge of mother tongue within the students - prospective foreign language teachers / lecturers, here we put an emphasize on prospective French language teachers / lecturers, also the knowledge of international culture (sociocultural knowledge), different skills for communication in various communicative situations (speaking, listening, reading and writing skills / comportements).

As we are referring to the modern means of teaching foreign language and culture there are means of educational process that are used by lecturers during the language training classes. The objective for forming the ICC components in students' educational process is authentic media resources (advertisement, comics, songs, printed band and digital format press, video and audio reports). While using these materials it becomes possible to create foreign environment during language training classes, the lecturer can do it for better formation of the ICC among students. Each type of the authentic media resource can be presented as a source of linguistic and non-linguistic information about the country, which is studied by foreign language and culture, furthermore, there is information about the world culture that should be presented with appropriate methodology.

Our future prospects foresee various methodological recommendations that can be used in the process of the ICC forming within students' educational process.

\section{References:}

1. Butenko N.Yu. (2006). Sotsial'na psykholohiya v reklami: navch. posib. [Social psychology in advertising]. Kyiv: KNEU. (in Ukrainian)

2. Zrazhevska N.I. (2006). Masova komunikatsiia i kultura [Mass communication and culture]. Cherkasi. (in Ukrainian)

3. Rusnak, D.A. (2017). Mobil'nyy keys «Reklama yak zasib formuvannya mizhkul turnoyi kompetentnosti: henderni, vikovi y etnichni stereotypy» dlya maybut- 
nikh uchyteliv / vykladachiv frantsuz'koyi movy. Keysova i podkast tekhnolohiyi formuvannya mizhkul'turnoyi kompetentnosti: Kolektyvna monohrafiya [Mobile case study for futures teachers of French: Advertising as the way of developing of intercultural competence: gender, age and national stereotypes. Case study and podcast technologies in developing of intercultural competence]. Bihych O.B. (Ed.); Kyiv: Vyd. tsentr KNLU. Kyiv: Editions of Kyiv national linguistic university, pp. 22-91. (in Ukrainian)

4. Shevarshynova E.I. (2016). Formyrovanye mezhkulturnoi kompetentsyy u studentov yazikovikh fakultetov sredstvamy anhloiazichnikh vydeo medyatekstov. Diss. kand. ped. nauk [Developing of intercultural competence at the students of language departments by the means of English-speaking video mediatexts. Dr. ped. sci. diss.]. Moscow. (in Russian)

5. Barthes R. (1964). Rhétorique de l'image. Communications, Recherches sémiologiques, no. 4, pp. 40-51.

6. Byram M., Gribkova B., Starkey H. (2002). Développer la dimension interculturelle dans l'enseignement des langues: une introduction pratique à l'usage des enseignants. Strasbourg, Conseil de l'Europe.

7. Cadre européen commun de référence pour les langues (Apprendre, enseigner, évaluer) (2002). Conseil de l'Europe, Didier.

8. Debyser F. (1975). Lecture des civilisations. BELC. Bureau pour l'enseignement de la langue et de la civilisation françaises à l'étranger,

9. Defays J.-M., Défour S. (2003). Le français langue étrangère et seconde: enseignement et apprentissage. Edition Mardage.

10. Eco U. (1988). Sémiotique et philosophie du langage, Paris, Presses universitaires de France.

11. Gardes J-C. (2002). Rire en Allemagne et en France. Le Français dans le monde, numéro spécial, Humour et enseignement des langues. Paris, CLE International, pp. 64-70.

12. Lázár Il., Huber-Kriegler M. (2007). Développer et évaluer la compétence en communication interculturelle: Un guide à l'usage des enseignants de langues et des formateurs d'enseignants. Strasbourg, Editions du Conseil de l'Europe.

13. Zarate G. (1986). Enseigner une culture étrangère. Paris: Hachette.

14. UNESCO (2013). Compétences interculturelles. Cadre conceptuel et opérationnel, Paris, UNESCO. 